Bull. Chem. Soc. Ethiop. 2013, 27(2), 169-178.

Printed in Ethiopia

ISSN 1011-3924

DOI: http://dx.doi.org/10.4314/bcse.v27i2.2

(c) 2013 Chemical Society of Ethiopia

\title{
CORRELATION AMONG PHENOLIC, TOXIC METALS AND ANTIOXIDANT ACTIVITY OF THE EXTRACTS OF PLANT SPECIES FROM SOUTHEAST SERBIA
}

\author{
D.A. Kostic, J.M. Velickovic ${ }^{*}$, S.S. Mitic, M.N. Mitic, S.S. Randjelovic, B.B. Arsic and A.N. \\ Pavlovic
}

Department of Chemistry, Faculty of Sciences and Mathematics, University of Niš, Višegradska 33, 18000 Niš, Serbia

(Received July 5, 2012; revised December 17, 2012)

\begin{abstract}
The content of metals, total phenols, flavonoids and antioxidant activities of different plant extracts, used in Serbian traditional medicine, were determined. Phenol content determined using UV-Vis spectrophotometer measurements at $765 \mathrm{~nm}$ in the tested plant extracts obtained by standard extraction procedure decreases in the order Origanum vulgare L. < Delphinum consolida L. < Cichorium intybus L. < Calendula officinalis L. The tested extracts, examined by DPPH (di(phenyl)-(2,4,6-trinitrophenyl)iminoazanium) method, showed high antioxidant activity that correlates significantly with the content of phenols and flavonoids. The contents of metals $(\mathrm{Zn}, \mathrm{Fe}, \mathrm{Cu}, \mathrm{Mn}, \mathrm{Cd}, \mathrm{Cr}, \mathrm{Pb})$ were determined by flame atomic absorption spectrometer. Toxic metals, such as $\mathrm{Cd}, \mathrm{Cr}, \mathrm{Pb}$, were not detected in the investigated plants. Content of other metals in plants and their extracts were low, except content of Fe. We examined the correlation of metals $(\mathrm{Zn}, \mathrm{Fe}, \mathrm{Cu}, \mathrm{Mn})$ and phenolic compounds content in the extracts using PCA (principal component analysis). The investigated plants from Southeastern Serbia are suitable for the preparation of teas and herbal extracts, due to the low content of toxic metals $(\mathrm{Zn}, \mathrm{Fe}, \mathrm{Cu}, \mathrm{Mn})$, the high content of phenolic compounds and high antioxidant activity.
\end{abstract}

KEY WORDS: Toxic metals, Phenols, Flavonoids, Antioxidant activity, Correlation analysis

\section{INTRODUCTION}

Humans consume and use different medicinal plants. Although medicinal plants are widely considered to pose less risk than synthetic drugs, they are not completely free of toxic or other side effects [1]. However, there is a considerable interest in identifying natural antioxidants isolated from plants that protect them against free radical damage as an alternative to synthetic medicines [2,3]. Phenolic compounds from plants belong to class of bioactive components with antioxidant activities. Plant phenols represent an important group of natural antioxidants (phenolic acids, flavons, isoflavones, flavan-3-ols, antocyans, protoantocyans, tannins, etc), which show beside antioxidant activity, antimutagenic, anticancer, antiinflammatory, anti-ulcus and antimicrobial properties, and also decrease the risk of cardiovascular diseases [2,3].

Although the effectiveness of medicinal plants is mainly associated with their constituents, it was found that their prolonged intake can cause health problems due to possible presence of toxic metals [4]. Plants can be easily contaminated with toxic metals during cultivation. Also the contamination of herbal product can happen during processing. Because of the possibility of accumulation of toxic metals in plants, there is an increasing interest in determination of their contents. The human body requires both metallic and nonmetallic elements within certain permissible limits for growth and good health. Therefore, determination of content of elements in food and related products is essential for understanding their nutritive importance. Unfortunately, presence of some metals in large quantities in body may have a toxic effect [4-7]. Therefore, control of toxic metals in medicinal plants and their products should be made in order to ensure the safety and efficacy of herbal products [8].

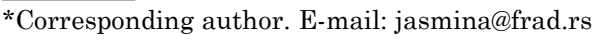


It is well known that wild plants are richer in polyphenol compounds than grown species. Because of the mentioned reasons, we investigated the following plants: Cichorium intybus L. (flower), Calendula officinalis L. (flower), Origanum vulgare L. (flower), and Delphinum consolida L. (flower). The plants were selected on the availability of the material and existing studies on their medicinal use (anti-inflammatory, antidiabetic, antihypertensive, anticancer and antiviral activity) in traditional Serbian medicine [9-12].

Cichorium intybus L. is known in folk medicine as an antidiabetic because all plants from the family Compositae have inulin as reserve food. Cichorium intybus L. has been used to treat skin disorders, such as gout, because of its antihepatotoxic activity, also [13, 14]. Calendula officinalis L. is a plant from the family Asteraceae. It has antibacterial and bactericidal effect, therefore, it is used for the treatment of wounds, psoriasis, etc. [15]. Calendula officinalis L. (flower) is known for its anti-inflammatory and anti-cancer properties [16]. Origanum vulgare L. is a plant from the family Lamiaceae. It has antispasmodic, bronchodilating, and diuretic effect $[17,18]$. Delphinum consolida L. is a plant from the family Ranunculaceae. It is used to treat intestinal worms, fluid retention, poor appetite, and trouble sleeping (insomnia). It is also used as a sedative to cause relaxation [19].

There are no studies on investigation of extracts of these species regarding the total content of phenolic compounds, concentrations of toxic metals and their antioxidant activity. The objective of the work was finding possible correlations among metals, amounts of phenolic compounds and the antioxidant activity of the investigated plant species extracts using principal component analysis and determination of possible similarities among the samples.

\section{Collecting of materials}

\section{EXPERIMENTAL}

The plant material was collected in the phase of blossoming from the natural habitats of the plants (Table 1) in the flowering stage, in the region of Southeast Serbia in July 2009. The studied area is located close to the city of Niš. Niš has about 300,000 inhabitants and represents one of the biggest cities in Serbia after Belgrade, but industry in this area is very poorly developed. Sample sites were selected in accordance with the methods used in the European moss monitoring project [20] differing in some climatic characteristics and altitude. A minimum distance of $300 \mathrm{~m}$ to major roads and larger settlements was required, a minimum distance of $100 \mathrm{~m}$ to minor roads and houses and a minimum distance of $5 \mathrm{~m}$ to forest roads (Table 1).

Table 1. Description and therapeutic significance of plant species used in this study.

\begin{tabular}{|l|l|l|l|l|}
\hline Plant & Binomial name & $\begin{array}{l}\text { Investigated } \\
\text { part }\end{array}$ & Therapeutic significance & Ref. \\
\hline $\begin{array}{l}\text { Common } \\
\text { chicory }\end{array}$ & $\begin{array}{l}\text { Cichorium } \\
\text { intybus } \text { L. }\end{array}$ & Flower & $\begin{array}{l}\text { Treatment of skin diseases, diabetes, anti- } \\
\text { hepatotoxic activity }\end{array}$ & 13,14 \\
\hline $\begin{array}{l}\text { Pot } \\
\text { marigold }\end{array}$ & $\begin{array}{l}\text { Calendula } \\
\text { officinalis } \text { L. }\end{array}$ & Flower & $\begin{array}{l}\text { Antibacterial and bactericidal effect, anti- } \\
\text { inflammatory and anti-carcinogenic activity }\end{array}$ & 15,16 \\
\hline Oregano & $\begin{array}{l}\text { Origanum } \\
\text { vulgare } \text { L. }\end{array}$ & flower & $\begin{array}{l}\text { Antispasmodic, bronchodilatation and diuretic } \\
\text { effect }\end{array}$ & 17,18 \\
\hline $\begin{array}{l}\text { Forking } \\
\text { larkspur }\end{array}$ & $\begin{array}{l}\text { Delphinium } \\
\text { consolida } \text { L. }\end{array}$ & Flower & $\begin{array}{l}\text { intestinal worms, fluid retention, poor appetite, and } \\
\text { trouble sleeping (insomnia), sedative }\end{array}$ & 19 \\
\hline
\end{tabular}

\section{Instrumentation}

Determinations of $\mathrm{Cd}, \mathrm{Pb}, \mathrm{Cr}, \mathrm{Fe}, \mathrm{Mn}, \mathrm{Cu}$ and $\mathrm{Zn}$ were performed using a flame atomic absorption spectrometer (Varian USA, type SpectrAA-20), equipped with hollow cathode 
lamps. Absorbance measures were carried out in area integration mode. Samples were prepared in triplicate and their signals subtracted from their blanks.

Determinations of the total phenols and flavonoids were performed using a Hewlett Packard UV-Vis spectrophotometer. For the phenolic compounds, a wavelength of $765 \mathrm{~nm}$ was used, and for the flavonoids, a wavelength of $420 \mathrm{~nm}$. Free radical scavenging activity was monitored at the wavelength of $517 \mathrm{~nm}$.

\section{Chemicals and reagents}

DPPH, quercetin and $\mathrm{AlCl}_{3}$ were purchased from Sigma Chemical Co. (St. Louis, MO, USA). Folin-Ciocalteu's phenol reagent and sodium carbonate were purchased from Merck Chemical Suppliers (Darmstadt, Germany). Sodium chlorate buffer (pH 1.0) and acetate buffer ( $\mathrm{pH} 4.5$ ) were purchased from the same producer. All other used chemicals, including solvents, were of analytical grade Sigma-Aldrich (GmbH, Sterbeim, Germany). The working solutions were prepared immediately before the analysis from the basic solution (concentration $1000 \mathrm{mg} \mathrm{L}^{-1}$ for all metals). For the preparation of standard solutions high purity Milli-Q water was used. The glassware and polyethylene containers used for analysis were washed with tap water, then soaked over the night in $6 \mathrm{M} \mathrm{HNO}_{3}$ solution and rinsed several times with ultra pure water to eliminate absorbance due to detergent.

\section{Determination of toxic metals}

The standard procedure for the determination of toxic metals described in AOAC (2000) was followed for the preparation of samples for the analysis [21]. Accurately weighted (2 g) sample was transferred into a silica crucible and kept in a muffle furnace for ashing at $450{ }^{\circ} \mathrm{C}$ for $3 \mathrm{~h}$ and then $5 \mathrm{~mL}$ of $6 \mathrm{M} \mathrm{HCl}$ was added to the crucible. Care was taken to ensure that all ash came into contact with acid. Further, the crucible containing acid solution was kept on a hot plate and digested to obtain a clean solution. The final residue was dissolved in $0.1 \mathrm{M} \mathrm{HNO}_{3}$ solution and made up to $50 \mathrm{~mL}$. Working standard solutions were prepared by diluting the stock solution (prepared solution), with $0.1 \mathrm{M}$ nitric acid in order to check the linearity.

\section{Preparation of herbal extracts}

Dried material (flowers) of plant species was ground in a blender. Samples of $1 \mathrm{~g}$ of each species were weighted from the ground and homogenized herb and extracted with solvents listed in Table 2. The extraction was carried out for 15 min three times with 30,20 , and $20 \mathrm{~mL}$ of solvent, respectively. The selected solvents were: ethanol, ethanol-water: 50-50, v/v (\%), and water. The extraction was performed in an ultrasonic bath. The extracts were filtered through a Buchner funnel and filter paper (blue collar), (CHMLAB, Spain), transferred into a normal 100 $\mathrm{mL}$ flask and the same solvent was added to the mark.

\section{Determination of the total phenolics}

Total phenol contents in the extracts were determined by the modified Folin-Ciocalteu method [22]. An aliquot of the extracts $(1 \mathrm{~mL})$ was mixed with $0.5 \mathrm{~mL}$ of Folin-Ciocalteu reagent and $1.5 \mathrm{~mL}$ of sodium carbonate solution (20\%). Tubes were vortexed for $15 \mathrm{~s}$ and allowed to stand at $40{ }^{\circ} \mathrm{C}$ for $30 \mathrm{~min}$ in order to develop color. Total phenol content was expressed as $\mathrm{mg} \mathrm{g}^{-1}$ of gallic acid equivalent (GAE). 
Determination of total flavonoid content

Total flavonoid contents were determined using the spectrophotmetric method based on the formation of flavonoid complex with aluminum [23]. A volume of $0.5 \mathrm{~mL}$ of $2 \% \mathrm{AlCl}_{3}$ methanol solution was added to $0.5 \mathrm{~mL}$ of sample solution. After one hour at room temperature, the absorbance was measured at $420 \mathrm{~nm}$. The yellow color indicated that the extracts contained flavonoids. Total flavonoid content was calculated as concentration of quercetin $\left(\mathrm{mg} \mathrm{g}^{-1}\right)$ using the equation based on the calibration curve.

Free radical scavenging activity

The free radical scavenging activity of the plant extracts was analyzed by using the DPPH method $[24,25]$. The antioxidant assay is based on the measurement of the loss of color of DPPH solution by the change of absorbance at $517 \mathrm{~nm}$ caused by the reaction of DPPH with the tested sample. Plant extracts $(0.2 \mathrm{~mL})$ and $1.8 \mathrm{~mL}$ of freshly prepared $\mathrm{DPPH}$ in methanol (20 $\mathrm{mg} \mathrm{L}^{-1}$ ) was put into a cuvette at room temperature. After 20 min of incubation period at room temperature, the absorbance was read against a blank probe at $517 \mathrm{~nm}$. An inhibition of DPPH in percents (RSC \%) of each plant extract sample was calculated from the decrease of absorbance according to the relationship:

$$
\operatorname{RSC}(\%)=\left(1-\mathrm{A}_{\text {sample }} / \mathrm{A}_{\text {blank }}\right) \times 100(\%)
$$

where $A_{\text {blank }}$ is the absorbance of control reaction, and $A_{\text {sample }}$ is the absorbance of the tested sample.

\section{Statistical analysis}

The experimental results were expressed as mean value \pm standard error of mean value of three replicates. In order to estimate statistically any significant differences among mean values, where applicable, the data were subjected to a one-way analysis of variance (ANOVA test), and differences among samples were determined by Duncan's Multiple Range test using the Statistical Analysis System software [26].

Analyses of correlations among the evaluated parameters

The used statistical tool was PCA. PCA permits the evaluation of the data set, reducing its dimension, conserving most of the useful statistical information present in the original data. Data are presented as the mean \pm standard deviation (SD) for triplicate determinations. PCA is used to establish the relationships among variable. The analysis was performed using a statistical package running on a desktop computer (Statistica 8.0, StatSoft, Inc, Tulsa, OK, USA).

\section{RESULTS AND DISCUSSION}

In our work the content of total phenols, flavonoids, antioxidant activities and toxic metals (Fe, $\mathrm{Zn}, \mathrm{Cu}$, and $\mathrm{Mn}$ ) were determined in the investigated plant extracts from the region of Southeast Serbia (Table 2). The content of the total phenols in the extracts of the investigated plants was determined using Folin-Ciocalteu method and was expressed as GAE $\mathrm{g}^{-1}$ of the fresh sample (Table 2). 
Table 2. Comparative study of total phenols, flavonoids, toxic metals content and antioxidant activities in the investigated plant extracts.

\begin{tabular}{|c|c|c|c|c|c|c|c|c|c|}
\hline \multirow{2}{*}{$\begin{array}{l}\text { Plan } \\
t\end{array}$} & \multirow[b]{2}{*}{ Extract } & \multirow{2}{*}{$\begin{array}{c}\text { Total } \\
\text { phenols } \\
\text { content }^{\mathrm{a}}\end{array}$} & \multirow{2}{*}{$\begin{array}{c}\text { Flavonoid } \\
\text { content }^{b}\end{array}$} & \multicolumn{2}{|c|}{ Antioxidant activity } & \multirow{2}{*}{$\begin{array}{c}\mathrm{Fe} \\
\mathrm{mg} \mathrm{kg}^{-1}\end{array}$} & \multirow{2}{*}{$\begin{array}{c}\mathrm{Zn} \\
\mathrm{mg} \mathrm{kg}^{-1}\end{array}$} & \multirow{2}{*}{$\begin{array}{c}\mathrm{Cu} \\
\mathrm{mg} \mathrm{kg}^{-1}\end{array}$} & \multirow{2}{*}{$\begin{array}{c}\mathrm{Mn} \\
\mathrm{mg} \mathrm{kg}^{-1}\end{array}$} \\
\hline & & & & $\begin{array}{c}\text { (RSC) in } \\
(\%)\end{array}$ & $(\mathrm{RSC})^{\mathrm{c}}$ & & & & \\
\hline \multirow{4}{*}{ 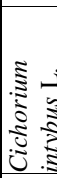 } & Plant & & & & & $402 \pm 8$ & $32.4 \pm 0.6$ & $20.5 \pm 0.4$ & $49.4 \pm 1.0$ \\
\hline & Water & $8.6 \pm 0.2$ & $0.6 \pm 0.0$ & $67.0 \pm 5.1$ & $8.2 \pm 0.0$ & - & - & $1.1 \pm 0.0$ & - \\
\hline & Ethanol & $5.3 \pm 0.8$ & $0.2 \pm 0.0$ & $92.1 \pm 0.7$ & $1.3 \pm 0.0$ & $68.0 \pm 0.6$ & $28.8 \pm 0.6$ & $8.5 \pm 0.2$ & $7.2 \pm 0.1$ \\
\hline & $\begin{array}{l}\text { Ethanol-water } \\
(50 / 50, \mathrm{v} / \mathrm{v}(\%))\end{array}$ & $4.8 \pm 0.0$ & $0.3 \pm 0.0$ & $86.6 \pm 0.2$ & $2.8 \pm 0.0$ & $29.0 \pm 0.6$ & $3.7 \pm 0.1$ & $3.2 \pm 0.1$ & $4.8 \pm 0.1$ \\
\hline \multirow{4}{*}{ 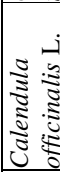 } & Plant & & & & & $137 \pm 3$ & $18.1 \pm 0.4$ & $12.8 \pm 0.3$ & $24.4 \pm 0.5$ \\
\hline & Water & $45.1 \pm 0.0$ & $0.1 \pm 0.00$ & $85.2 \pm 0.3$ & $3.2 \pm 0.2$ & $16.0 \pm 0.3$ & $4.5 \pm 0.1$ & $1.5 \pm 0.0$ & $5.4 \pm 0.1$ \\
\hline & Ethanol & $31.9 \pm 1.1$ & $0.1 \pm 0.0$ & $27.3 \pm 1.2$ & $19.2 \pm 0.0$ & $76.0 \pm 1.6$ & $5.3 \pm 0.1$ & $2.4 \pm 0.0$ & $13.7 \pm 0.3$ \\
\hline & $\begin{array}{l}\text { ethanol-water } \\
(50 / 50, \mathrm{v} / \mathrm{v}(\%))\end{array}$ & $29.8 \pm 0.7$ & $0.2 \pm 0.0$ & $96.8 \pm 0.3$ & $0.0 \pm 0.0$ & $17.0 \pm 0.3$ & $4.4 \pm 0.1$ & $1.1 \pm 0.0$ & $3.6 \pm 0.1$ \\
\hline \multirow{4}{*}{ 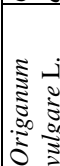 } & Plant & & & & & $152 \pm 3$ & $49.6 \pm 1.0$ & $23.9 \pm 0.5$ & $21.8 \pm 0.4$ \\
\hline & Water & $74.3 \pm 1.2$ & $2.1 \pm 0.0$ & $75.1 \pm 0.4$ & $6.0 \pm 0.1$ & - & $29.1 \pm 0.6$ & $4.5 \pm 0.1$ & - \\
\hline & Ethanol & $23.6 \pm 0.4$ & $1.0 \pm 0.0$ & $93.8 \pm 0.4$ & $0.8 \pm 0.1$ & $113 \pm 2$ & $22.3 \pm 0.4$ & $3.8 \pm 0.1$ & $16.3 \pm 0.3$ \\
\hline & $\begin{array}{l}\text { ethanol-water } \\
(50 / 50, \mathrm{v} / \mathrm{v}(\%))\end{array}$ & $75.2 \pm 0.6$ & $2.0 \pm 0.0$ & $87.2 \pm 1.1$ & $2.6 \pm 0.0$ & - & $22.0 \pm 0.4$ & $0.4 \pm 0.1$ & - \\
\hline \multirow{4}{*}{ 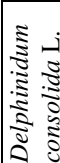 } & Plant & & & & & $286 \pm 6$ & $39.8 \pm 0.8$ & $23.1 \pm 0.5$ & $13.8 \pm 0.3$ \\
\hline & Water & $24.2 \pm 0.4$ & $1.7 \pm 0.0$ & $82.7 \pm 1.7$ & $3.8 \pm 0.0$ & $14.0 \pm 0.3$ & $11.0 \pm 0.2$ & & - \\
\hline & Ethanol & $23.9 \pm 1.8$ & $1.1 \pm 0.0$ & $32.5 \pm 3.1$ & $17.7 \pm 0.0$ & $176 \pm 4$ & $14.0 \pm 0.3$ & $18.8 \pm 0.4$ & $3.3 \pm 0.1$ \\
\hline & $\begin{array}{l}\text { ethanol-water } \\
(50 / 50, \mathrm{v} / \mathrm{v}(\%))\end{array}$ & $18.3 \pm 0.4$ & $1.3 \pm 0.0$ & $94.4 \pm 0.1$ & $0.6 \pm 0.1$ & - & $12.2 \pm 0.2$ & $3.6 \pm 0.1$ & - \\
\hline
\end{tabular}

${ }^{\mathrm{a}}$ Expressed as mg of gallic acid g ${ }^{-1}$ of dry sample. ${ }^{\mathrm{b}}$ Expressed as mg of quercetin $\mathrm{g}^{-1}$ of dry sample. ${ }^{\mathrm{c}}$ Expressed as $\mathrm{mg}$ of quercetin $\mathrm{g}^{-1}$ of dry sample.

Results showed that the content of total phenols in the investigated plants are very high and it is the highest in aqueous and (ethanol-water: $50 / 50, \mathrm{v} / \mathrm{v}(\%)$ ) extract of oregano (Origanum vulgare L.) more than $70 \mathrm{mg} \mathrm{GAE} \mathrm{g}^{-1}$ of dry sample. Phenol content in the tested plant extracts decreases in the order Origanum vulgare L.> Delphinum consolida L. > Cichorium intybus L. > Calendula officinalis $\mathrm{L}$. The content of phenols in water extracts is the highest. The difference in the total content of phenolic compounds depends on the extraction solution and it can be seen in all plants and it is a consequence of different polarity of used organic solvents which selectively extract some phenolic compounds. The content of phenols represents the pharmacological characteristic of the plant. In the case of medical herbs, the concentration of phenols goes from 0.2 to $2.8 \mathrm{mg} \mathrm{GAE} \mathrm{g}^{-1}$ of fresh sample, whereas the concentration of phenols in the case of feeding plants goes from 0.3 to $17.5 \mathrm{mg} \mathrm{GAE} \mathrm{g}^{-1}$ of fresh sample. On the basis of the literature data, the highest content of phenolic compounds is proved in plants from genus Origanum, around $20 \mathrm{mg} \mathrm{GAE} \mathrm{g}^{-1}$ of fresh sample than the other investigated plant species [27]. The content of total phenols in the flower of Calendula officinalis L. (UV spectrophotometric method, Folin-Ciocalteu method) is $15.1 \mathrm{mg} \mathrm{g}^{-1}$ sample and the content of the total flavonoids (Markham) is $5.1 \mathrm{mg} \mathrm{g}^{-1}$ of the sample [28].

The literature data for Origanum vulgare L. show that ORAC (capacity of the absorption of

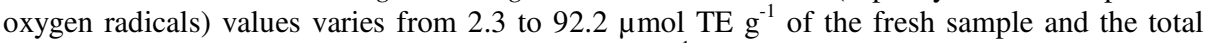
content of phenols varies from 0.3 to $17.5 \mathrm{mg} \mathrm{GAE} \mathrm{g}^{-1}$ of the fresh sample [27]. On the basis of the experimental results shown in Table 2, the content of total flavonoids in the extracts of the investigated plants is much lower than the phenol content. The content of total flavonoids is expressed in the form of $\mathrm{mg}$ of quercetin equivalent $\left(\mathrm{QE} \mathrm{g}^{-1}\right)$ per gram of dry sample. The contents of flavonoids in the tested plant extracts is high and decreases in the order Origanum 
vulgare L. > Calendula officinalis L. $>$ Delphinum consolida L. $>$ Cichorium intybus L. The content of flavonoids was the highest in the water and the lowest in the ethanolic extracts. These experimental results are expected because of the solubility of phenolics, flavonoids and their glucosides in water. Generaly, extracts of Origanum vulgare L. have the highest content of phenolic compounds.

Antioxidant activity of the extracts of the investigated plants was determined using DPPH method. Antioxidant activity of different extracts was investigated with spectrophotometric method using the ability of the extract to catch stable DPPH radicals. Antioxidant activity is expressed in percents and $\mathrm{mg}$ of quercetin-equivalents $(\mathrm{QE})$, i.e. solution of quercetin which shows identical activity as investigated extracts and the data are shown in Table 2. Most of the extracts showed antioxidant activity more than $80 \%$. Only ethanol extracts of plant Calendula Officinalis L. and Delfinidum consolida L. have low antioxidant activity, about 30\%. Similar value for the antioxidant activity for all investigated plants has an analogy to the similar content of total flavonoid compounds in investigated plant extracts. The antioxidant activity of the majority of plants is the highest in ethanol - water: 50/50, v/v (\%) extract. These experimental data are expected because of the solubility of flavonoids. DPPH radical scavenging abilities of the investigated extract showed that the extracts of tested extract contain molecules with protondonating ability and could serve as free radical inhibitors or scavengers, acting possibly as primary antioxidant. In comparing our results for the total phenol content, flavonoids and antioxidant activity for the investigated plant species from Southeast area of Serbia with the results of other authors, we can see the firm agreement. The contents of metals in plants and their extracts were determined. The presence of toxic metals in the extracts can be explained by the possible complex forming that occurs between the element and the organic compounds in the plants. The presence of metals in plants is the result of the transfer of metals from the soil, water and atmospheric precipitation during growth.

Among the considered metals contents, the iron content was the highest and varied from 138 up to $402 \mathrm{mg} \mathrm{kg}^{-1}$ plants. On the other hand, concentrations of $\mathrm{Cu}, \mathrm{Zn}$ and $\mathrm{Mn}$ were remarkably lower, and in the range between 12.8 and $49.6 \mathrm{mg} \mathrm{kg}^{-1}$ plants. The highest content of $\mathrm{Fe}$ is shown to be present in ethanolic extracts of Delphinidum consolida L. The quantities of other metals $(\mathrm{Cu}, \mathrm{Zn}$ and $\mathrm{Mn})$ are present in the highest quantity in the ethanolic solutions of the investigated plants. $\mathrm{Cd}, \mathrm{Pb}$ and $\mathrm{Cr}$ were not detected in any of the extracts. The presence of $\mathrm{Fe}$, $\mathrm{Cu}, \mathrm{Zn}$ and $\mathrm{Mn}$ in the ethanol extracts can be explained by the possible complex formation that occurs between the element and the organic compounds in the plants. Minerals are inorganic substances, present in all body tissues and fluids and their presence is necessary for the maintenance of certain physicochemical processes which are essential to life [4, 5]. These include calcification of bone, blood coagulation, neuromuscular activity, acid base equilibrium, enzyme activity, osmotic regulation. The correlation of the content of total phenolic, flavonoid compounds, contents of metals $(\mathrm{Zn}, \mathrm{Fe}, \mathrm{Cu}$ and $\mathrm{Mn})$ and antioxidant activity of the investigated extracts was determined, which is presented in Table 3 . Coefficient of correlation of total phenolic, flavonoids, content of metals $(\mathrm{Zn}, \mathrm{Fe}, \mathrm{Cu}$ and $\mathrm{Mn}$ ) and antioxidant activity of other plant species Cichorium intybus L. is very high (Table 4). Substantial coefficients of correlation are in investigated extracts of Origanum vulgare L. and Delphinidum consolida L and insignificant in extracts of Delfinidum Consolida L. The used statistical tool was PCA. Using PCA, it was possible to observe some correlations between metal ions and the level of flavonoids and among the levels of flavonoids and phenolic compounds with the antioxidant activity of plant species. Particularly, a direct correlation between Fe and $\mathrm{Mn}$ and total phenols and the amount of flavonoids (Origanum vulgare L.), and amount of flavonoids and $\mathrm{Zn}, \mathrm{Cu}$ and Mn content in extracts of Delphinidum Consolida L. were observed (Table 3). 
Table 3. Correlation coefficients of total phenolic, flavonoids, contents of toxic metals and antioxidant activity in the investigated extracts of plant species.

\begin{tabular}{|c|c|c|c|c|c|c|c|c|}
\hline Plant & - & \begin{tabular}{|l|}
$\begin{array}{l}\text { Total phenols } \\
\text { content }^{\mathrm{a}}\end{array}$ \\
\end{tabular} & Flavonoid content $^{b}$ & $\left(\mathrm{RSC}^{\mathrm{c}}\right.$ & $\begin{array}{l}\mathrm{Fe} \\
\mathrm{mg} \mathrm{kg}^{-1}\end{array}$ & $\begin{array}{l}\mathrm{Zn} \\
\mathrm{mg} \mathrm{kg}^{-1}\end{array}$ & $\begin{array}{l}\mathrm{Cu} \\
\mathrm{mg} \mathrm{kg}^{-1}\end{array}$ & $\begin{array}{l}\mathrm{Mn} \\
\mathrm{mg} \mathrm{kg}^{-1}\end{array}$ \\
\hline \multirow{7}{*}{ 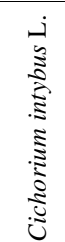 } & Total phenols content ${ }^{\mathrm{a}}$ & 1.0 & 0.8 & 0.9 & 0.5 & 0.2 & 0.4 & 0.8 \\
\hline & Flavonoid content ${ }^{b}$ & & 1.0 & 1.0 & 0.1 & 0.6 & 0.8 & 1.0 \\
\hline & $(\mathrm{RSC})^{\mathrm{C}}$ & & & 1.0 & 0.8 & 0.6 & 0.7 & 1.0 \\
\hline & $\mathrm{Fe}\left(\mathrm{mg} \mathrm{kg}^{-1}\right)$ & & & & 1.0 & 0.9 & 1.0 & 0.9 \\
\hline & $\mathrm{Zn}\left(\mathrm{mg} \mathrm{kg}^{-1}\right)$ & & & & & 1.0 & 1.0 & 0.7 \\
\hline & $\mathrm{Cu}\left(\mathrm{mg} \mathrm{kg}^{-1}\right)$ & & & & & & 1.0 & 0.8 \\
\hline & $\operatorname{Mn}\left(\mathrm{mg} \mathrm{kg}^{-1}\right)$ & & & & & & & 1.0 \\
\hline \multirow{7}{*}{ ن. } & Total phenols content ${ }^{\mathrm{a}}$ & 1.0 & 0.1 & 0.6 & 0.2 & 0.1 & 0.0 & 0.1 \\
\hline & Flavonoid content $^{\mathrm{b}}$ & & 1 & 0.7 & 0.5 & 0.6 & 0.8 & 0.7 \\
\hline & $(\mathrm{RSC})^{\mathrm{C}}$ & & & 1.0 & 1.0 & 1.0 & 1.0 & 1.0 \\
\hline & $\mathrm{Fe}\left(\mathrm{mg} \mathrm{kg}^{-1}\right)$ & & & & 1.0 & 1.0 & 0.9 & 1.0 \\
\hline & $\mathrm{Zn}\left(\mathrm{mg} \mathrm{kg}^{-1}\right)$ & & & & & 1.0 & 0.9 & 1.0 \\
\hline & $\mathrm{Cu}\left(\mathrm{mg} \mathrm{kg}^{-1}\right)$ & & & & & & 1.0 & 1.0 \\
\hline & $\operatorname{Mn}\left(\mathrm{mg} \mathrm{kg}^{-1}\right)$ & & & & & & & 1.0 \\
\hline \multirow{7}{*}{ 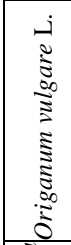 } & Total phenols content ${ }^{\mathrm{a}}$ & 1.0 & 1.0 & 0.6 & 1.0 & 0.2 & 0.1 & 1.0 \\
\hline & Flavonoid content $^{\mathrm{b}}$ & & 1.0 & 0.7 & 1.0 & 0.3 & 0.1 & 1.0 \\
\hline & $(\mathrm{RSC})^{\mathrm{C}}$ & & & 1.0 & 0.6 & 0.9 & 0.1 & 0.6 \\
\hline & $\mathrm{Fe}\left(\mathrm{mg} \mathrm{kg}^{-1}\right)$ & & & & 1.0 & 0.2 & 0.1 & 1.0 \\
\hline & $\mathrm{Zn}\left(\mathrm{mg} \mathrm{kg}^{-1}\right)$ & & & & & 1.0 & 0.4 & 0.2 \\
\hline & $\mathrm{Cu}\left(\mathrm{mg} \mathrm{kg}^{-1}\right)$ & & & & & & 1.0 & 0.1 \\
\hline & $\operatorname{Mn}\left(\mathrm{mg} \mathrm{kg}^{-1}\right)$ & & & & & & & 1.0 \\
\hline \multirow{3}{*}{\begin{tabular}{l}
5 \\
\multirow{3}{0}{} \\
$\vdots$ \\
$\vdots$ \\
0
\end{tabular}} & Total phenols content ${ }^{\mathrm{a}}$ & 1.0 & 0.2 & 0.4 & 0.3 & 0.0 & 0.1 & 0.2 \\
\hline & Flavonoid content ${ }^{\mathrm{b}}$ & & 1.0 & 0.5 & 0.6 & 0.9 & 1.0 & 0.1 \\
\hline & $\left(\right.$ RSC $^{\mathrm{c}}$ & & & 1.0 & 1.0 & 0.7 & 0.9 & 1.0 \\
\hline \multirow{4}{*}{ 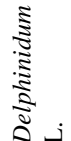 } & Total phenols content ${ }^{\mathrm{a}}$ & & & & 1.0 & 0.8 & 1.0 & 1.0 \\
\hline & $\mathrm{Zn}\left(\mathrm{mg} \mathrm{kg}^{-1}\right)$ & & & & & 1.0 & 0.9 & 0.8 \\
\hline & $\mathrm{Cu}\left(\mathrm{mg} \mathrm{kg}^{-1}\right)$ & & & & & & 1.0 & 1.0 \\
\hline & $\operatorname{Mn}\left(\mathrm{mg} \mathrm{kg}^{-1}\right)$ & & & & & & & 1.0 \\
\hline
\end{tabular}

${ }^{\mathrm{a}}$ Expressed as $\mathrm{mg}$ of gallic acid $\mathrm{g}^{-1}$ of dry sample. ${ }^{\mathrm{b}}$ Expressed as mg of quercetin $\mathrm{g}^{-1}$ of dry sample. ${ }^{\mathrm{c}}$ Expressed as $\mathrm{mg}$ of quercetin $\mathrm{g}^{-1}$ of dry sample.

Table 4. Correlation coefficients analysis.

\begin{tabular}{|l|l|}
\hline Correlation analysis & Values [29] \\
\hline The correlation is very high & $(0.9<|\mathrm{r}| \leq 1)$ \\
\hline The correlation is high & $(0.7<|\mathrm{r}| \leq 0.9)$ \\
\hline The correlation is substantial & $(0.5<|\mathrm{r}| \leq 0.7)$ \\
\hline The correlation is insignificant & $(0.2<|\mathrm{r}| \leq 0.5)$ \\
\hline The correlation is low & $(|\mathrm{r}| \leq 0.2))$ \\
\hline
\end{tabular}




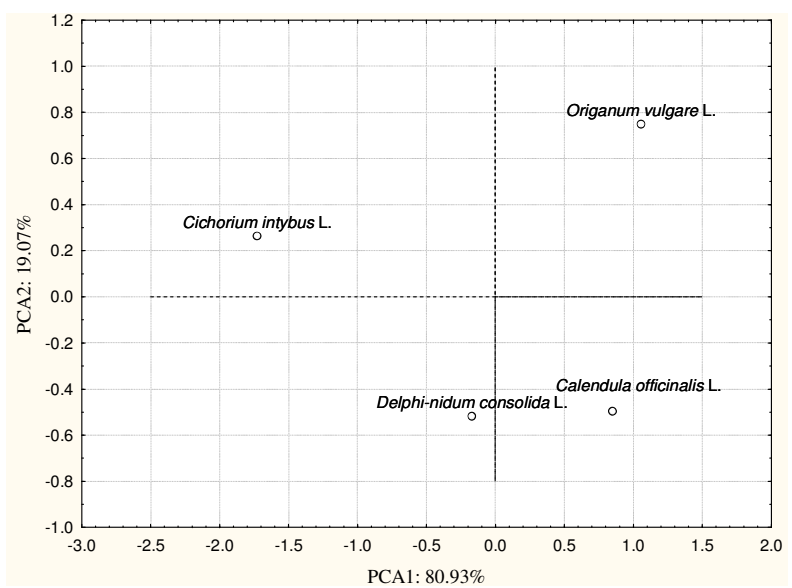

Figure 1. Principal component score plot (PC1 and PC2) of the studied plant samples based on total phenol content.

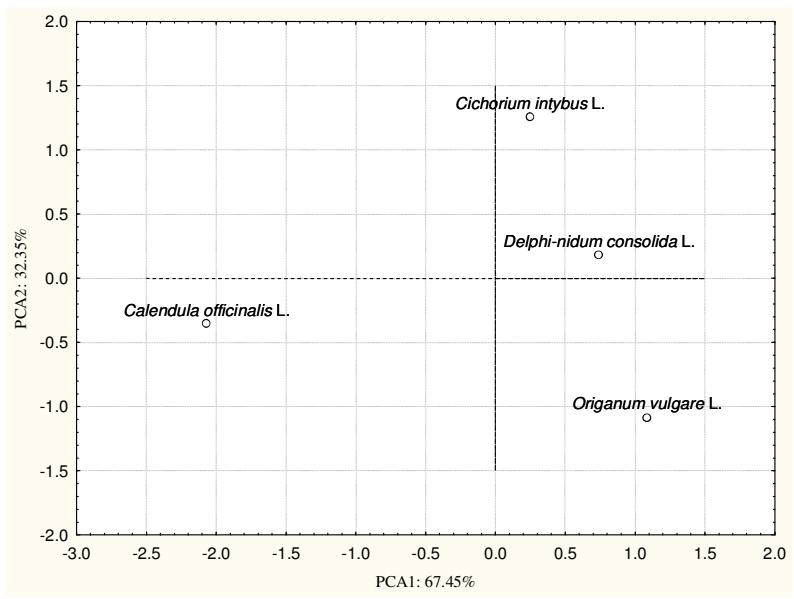

Figure 2. Principal component score plot (PC1 and PC2) of the studied plant samples based on metal content.

For better illustration, PCA was used to compare chemical analysis (total phenol and metal content) of selected plant samples. Actually, PCA was used to find out which manifest variables (metals and total phenols extracted from different solvents) are related to a specific principal component (latent variable) which is associated with a fundamental variable (plant samples). Each principal component (PC) is associated with an eigen value, PC1 has the largest eigen value and carries the largest variance of the original data and subsequent PCs carry variance in a decreasing order. Screen test proposed by Cattell [29] suggests that only the first two principal components (PCs) contained significant information. The PCA results graphically displayed plot. The score plot shows the relationships between the samples (plant samples). Each point whose coordinates are the scores on the principal components (axes on the plot) corresponds to a sample. When a sample has a high factor loading on a specific principal component, it means

Bull. Chem. Soc. Ethiop. 2013, 27(2) 
that the sample has a high value for the variable. The relation between PC1 which explained $80.9 \%$ of the total variance and PC2 which explained a further $19.1 \%$ based on total phenol content is shown in Figure 1.

From Figure 1, it can be noted that Origanum vulgare L. and Calendula officinalis L. have positive loadings on PC1. In other words, these two plants contain higher total phenols content than those at left-hand side. Also, the results indicate that the total phenol content in Origanum vulgare L. > Calendula officinalis L. > Delphinidum consolida $\mathrm{L} .>$ Cichorium intybus $\mathrm{L}$.

In the case of metal content in selected plant samples in Figure 2, PC1 includes 67.4\% and the second PC includes $32.3 \%$ of the total variance in the data set and has high positive loadings for the Cichorium intybus L., Delphinidum consolida L. and Origanum vulgare L., Calendula officinalis $\mathrm{L}$. have a negative score in PC2.

On the basis of numerous studies it was known that the content of polyphenol compounds depends on genotype, soil conditions and the difference in fruits' repining [30]. Also, outdoor conditions, like altitude, light, temperature, the content of feeding material in soil can have an effect on the phenylpropanoids metabolism [31].

The comparison of our results regarding the content of toxic metals in plants from the region of Southeast Serbia with the results of other authors showed considerable agreement. The content of copper in Palestinian plants varied from 7.1 to $19.2 \mathrm{mg} \mathrm{kg}^{-1}$, and of zinc from 17.4 to $65.8 \mathrm{mg} \mathrm{kg}^{-1}$ [5]. The copper content in the black tea originating from the region of South India varies between 15.9 and $32.2 \mathrm{mg} \mathrm{kg}^{-1}$. In the plants from the region of Southeast Serbia, the highest content is that of iron, while the contents of $\mathrm{Zn}, \mathrm{Cu}$, and $\mathrm{Mn}$ are significantly lower. Certain quantities of toxic metals in plants are below the limit acceptable for the medicinal plants. Toxic metals, such as $\mathrm{Cd}, \mathrm{Cr}$ and $\mathrm{Pb}$ were not detected in the investigated plants. This can be attributed, among other factors, to the fact that these were autochthonous plants growing in a non-polluted region of Southeast Serbia. Such medicinal plants can safely be used in form of herbal infusions and extracts for the treatment of various diseases. In the black tea samples originating from the region of Iran, the copper concentration is within the range from 17.6 to $32.8 \mathrm{mg} \mathrm{kg}^{-1}$, and in water extracts from 1.1 to $1.6 \mathrm{mg} \mathrm{kg}^{-1}$ [32]. The iron concentration in medicinal plant from Turkey ranges from 2.4 to $107 \mathrm{mg} \mathrm{kg}^{-1}$, zinc from 3.9 to $18.0 \mathrm{mg} \mathrm{kg}^{-1}$, and copper from 2.4 to $8.1 \mathrm{mg} \mathrm{kg}^{-1}$ [33]. Comparing our results with results of authors from other countries showed that the content of toxic metals is similar or smaller. Based on these results, we recommend the use of water extracts with lower abundance of toxic metals.

\section{CONCLUSIONS}

The present study showed that the total phenol content from the plant extracts used in traditional Serbian medicine decreases in the order Origanum vulgare L. < Delphinum consolida L. < Cichorium intybus L. $<$ Calendula officinalis L. The standard DPPH method was used for the determination of the antioxidant activities of the extracts which showed significant correlation with the total phenol and flavonoid content. Toxic metals, such as $\mathrm{Cd}, \mathrm{Cr}$ and $\mathrm{Pb}$, were not detected in the investigated plants. The content of toxic metals $(\mathrm{Zn}, \mathrm{Fe}, \mathrm{Cu}, \mathrm{Mn}$ ) were low. Therefore, the extracts from the investigated plants are suitable for making herbal teas and cosmetic and pharmaceutical products.

\section{ACKNOWLEDGEMENTS}

Biljana Arsic greatly acknowledges financial support from the Serbian Ministry of Education and Science, Project No. 174007. The other authors acknowledge financial support from the Serbian Ministry of Education and Science, Project No. 174027. 


\section{REFERENCES}

1. De Smet, P.A.G.M. Clin. Pharmacol. Ther. 2004, 76, 1.

2. Nikolić, G.; Nikolić, S.; Milić, B.; Čanadanović-Brunet, J. Acta Fac. Med. Naiss. 1998, 15, 183.

3. Ivanova, D.; Gerova, D.; Chervenkov, T.; Yankova, T. J. Ethnoharm. 2005, 96, 145.

4. Jabeen, S.; Tahir Shah, M.; Khan, S.; Havat, M.Q. J. Med. Plants Res. 2010, 4, 559.

5. Khan, S.A.; Khan, L.; Hussain, I.; Marwat, K.B.; Akhtar, N. Pak. J. Weed Sci. Res. 2008, 14, 101.

6. Sharma, K.R.; Agrawal, M.; Marshall, M F. Food Chem. Toxicol. 2009, 47, 583.

7. WHO, Quality Control Methods for Medicinal Plant Materials, Revised, WHO: Geneva; 2005.

8. Nookabkaew, S.; Rangkadilok, N.; Satayavivad, J. J. Agr. Food Chem. 2006, 54, 6939.

9. Shahidi, F.; Naczk, M. Food Phenolics: An overview in Food Phenolics: Sources, Chemistry, Effects and Applications, Technomic Publishing Co: Pennsylvania, USA; 1995; pp 1-4.

10. Zargari, A. Medical Plants, Vol. 1, Tehran University Publications: Tehran; 1994; p 91.

11. List, P.H.; Horhammer, L. Hagers Handbuch der Pharmazeutischen Praxis, Springer, Berlin; 1971; p 6.

12. Borkowski, B.; Lutomski, J.; Skrzydlewska, E.; Zygmunt, B. Rosliny Lecznicze w Fitoterapii (Medicinal Plants in Phytotherapy), IriPZ: Poznan; 1994.

13. Ahmed, B.; Al-Howiriny, T.A.; Siddiqui, A.B. J. Ethnopharmacol. 2003, 87, 237.

14. Zafar, R. ; Ali, S.M. J. Ethnopharmacol. 1998, 63. 227. 15. Slavkovska,V.; Jancic, R.; Bojovics, S.; Milosavljevic, S.; Djokovic, D. Phytochemistry 2001, 57, 71 .

16. Bilia, A.R.; Bergonzi, M.C.; Gallori, S.; Mazzi, G. J. Pharm. Biomed. Anal. 2002, 15, 613.

17. Ietswaart, J.H.A. Taxonomic Revision of the Genus Origanum (Labiatae), Leiden University Press: The Hague; 1980.

18. Lawrence, B.M. Perfum. Flavor. 1984, 9, 41.

19. Olsen, J.D.; Manners, G.D.; Pelletier, S.W. Collectanea Bot. (Barcelona) 1990, 19, 141.

20. Zechmeister, H.G.; Hohenwallner, D.; Riss, A.; Hanus-Illnar, A. Sci. Total. Environ. 2003, $301,55$.

21. AOAC Official Methods of Analysis, Association of Official Analytical Chemist, EUAssociation: Marilend, USA; 2000.

22. Singleton, V.L.; Rossi, J.A. Am. J. Enol. Viticult. 1965, 16, 144.

23. Ordonez, A.A.L.; Gomez, J.D.; Vattuone, M.A.; Isla, M.I. Food Chem. 2006, 97, 452.

24. Fuhrman, B.; Volkova, N.; Suraski, A.; Aviram M. J. Agric. Food Chem. 2001, 46, 3164.

25. Sanchez-Moreno, J.; Larrauri, J.A.; Saura-Calixto F. J. Agric. Food Chem. 1999, 79, 1301.

26. Statistical Analysis and Reporting System, User Guide, Version 1.0, IBM; 1999.

27. Zheng, W.; Wang, S.Y. J. Agric. Food Chem. 2001, 49, 5165.

28. Ćetković, G.S.; Đilas, S.M.; Čanadanović-Brunet, J.M.; Tumbas, V.A.T. APTEFF, 2003, 34, 93.

29. Cattell, R. B. Multivar. Behav. Res. 1996, 1, 245.

30. Orhan, D.D.; Hartevioğlu, A.; Küpeli, E.; Yesilada E. J. Ethnopharmacol. 2007, 112, 394.

31. Dixon, R.A.; Paiva, N.L. Plant Cell 1995, 7, 1085.

32. Karimi, G.; Hasanzadeh, M.K.; Nili, A.; Khashayarmanesh, Z.; Samiei, Z.; Nazari, F.; Teimuri, M. Pharmacology 2008, 3, 164.

33. Basgel, S.; Erdemoglu, S.B. Sci.Total Environ. 2006, 359, 82. 